\title{
THE EXAMINATION OF COMPETENCE: COMPETENCE IN INTERNATIONAL COMMERCIAL ARBITRATION
}

\author{
Homayoun Mafi ${ }^{1}$ \\ Mohammad Reza Khademi ${ }^{2}$
}

\begin{abstract}
The arbitration clause implies issues that may arise in arbitration is the the agreement of the parties' will to concede (assign) the existing or future dispute into arbitration, thus, in accordance with the law, the inevitable basis is to establish the referee's authority and jurisdiction and the influence of his/her verdict. Therefore, the formation of a court of arbitration and the issuance of a ruling requires that the existence and the validity of the contract of referral the matter to arbitration is acceptable to the parties. Although the parties may find a dispute (difference) in the existence and validity of the arbitration agreement, it is also determination of the competent authority dealing with a dispute that may arise between the parties as to the existence or validity of the arbitration convention or jurisdiction. The issue of competency assessment (Competence Competence), which improves the efficiency of the arbitral institution, can be seen in the most legal systems. Whether the arbitral tribunal has the merit of deciding whether to qualify under the terms of the arbitral agreement is a question that has long been addressed in the arbitration law as the competence to determine jurisdiction.
\end{abstract} likely that one of the parties denies or invalidates the existence of the arbitration agreement. In such a hypothesis, the formation of an arbitration authority and its review will entail consideration of the dispute before it. For this reason, one of the important

Keywords: Competence -competence, International commercial arbitration, Jurisdiction, Arbitrator

\section{Competence}

\footnotetext{
${ }^{1}$ Associate Professor, Department of Law, University of Judicial Sciences and Administrative Services, Tehran, Iran.

${ }^{2}$ Ph.D. student of Private Law, University of Mazandaran, Babolsar, Iran. Corresponding Author Email: khademix@gmail.com.
} 
The parties, referring the resolution of the dispute to the arbitration order, shall at the same time award jurisdiction to the arbitrators. The optional nature of the arbitration shall be the basis for the establishment of qualification rule for the referees. In cases where arbitration is also compulsory, the legal provisions arising from the founding or treaties and the outcome of the will of the states, create the abovementioned competence (Dr. Ahmad Amir Moezi-International arbitration in commercial cases- page 251).

One of the effects of the competence - competence doctrine is the possibility of reviewing the competence of the referees in the assumption of objection to it by the arbitrator or the arbitral tribunal. It is also possible to review this matter after the judge or judges through the judicial authorities.

The reviewing authority may, in the case of a dispute, can rule on its competence (jurisdiction). That is, the judiciary (referee) can determine independently whether it has the discretion to resolve a particular dispute without requiring court authorization, even if the judiciary can first decide on
404

its jurisdiction (competence), the courts will not been completely exclude (Homayoun Mafi, page, 207).

The suitability (merit) of the arbitral tribunal to decide on its jurisdiction (competence) is the inherent authority of the dispute resolution authorities, including arbitration tribunals, and is an essential element in ensuring the ability and capability of the judges to perform their duties, and therefore we should not attempt to justify it on the basis of foreign foundations. The competency to determine the competence (competence - competence) is an effective rule designed to minimize the complications of unjustified objectionable protests against the jurisdiction of the arbitral tribunal. Given that the qualification competency doctrine, gives the authority and competence of decision-making to jurisdiction (arbitral tribunal), thus, it promotes the efficiency of the arbitration body, since there is no longer any need to go through the time frame and costs of hearing a judge in order to obtain a judicial decision on the jurisdiction of the court of arbitration (arbitral tribunal) (Ibrahim FI Shihata- page 25-26). 


\subsection{Definition of Competency}

Qualification in the word means being qualified and having competence (Mohammad Moein-p. 2195).

The power to do things for the official in the law, as well as for government-affiliated agents, such as the editors, is called intrinsic qualification. In relation to the field of actions, they say about judicial as jurisdiction (Mohammad Jafari Jafari Langroudi). Therefore, competency (jurisdiction) in terms of concept is the duty and right that judicial authorities (judiciary or administrative) have in law, in cases of litigation, complaints, and special affairs (Abdullah Shams-vol 1, p. 374). In fact, in the position of a dispute and resolution of a dispute, the person must refer to the authority competent to deal with, in this sense, the competency (jurisdiction), qualification is the ability, right and duty which, according to the law, judicial and non-judicial authorities have in dealing with claims and complaints and disputes about it. It is from this same point that qualification (competency) is defined as such: Qualification (competency) is an option given to a court to deal with a dispute and issue a ruling thereon. This option is provided by law in accordance with a special order (in the case of specialized courts) or in accordance with a general ruling (in the case of public courts) (Ahmad Matin Daftari, Vol. 1, p. 208) (in the case of specialized courts) or in accordance with a general ruling (in the case of public courts) (Ahmad Matin Daftari, Vol. 1, p. 208).

Although the discretion (authority) and jurisdiction of judges to decide on their own jurisdiction (competency) is generally recognized, the existence and basis of such jurisdiction (competency) hasn't been completely resolved (Barcelo, p. 1123).

\subsubsection{Principles of Determining the Jurisdiction (Competency) of the Referring Court}

By looking at the historical record of arbitration, one can find that the root of the arbitration should be sought in the context of a public prosecutor's vacancy, so that at that time, arbitration was considered as the only solution to the dispute, while at the same time, despite the establishment of state judiciary bodies, and while referring to them through the normal way to resolve 
disputes, arbitration continued its life mainly for this that the parties to the dispute were willing to resolve their disputes with less fines and costs and more rapidly by those who were involved in their election. This desire and the need to respect it led to in the credible system of proceedings the arbitration rules in more or less accurate manner to be developed (Abdullah Shams third c - page 516).

\section{Referring the matter to} arbitration is based on an agreement between the parties, while, in some cases, the legislator has considered sufficient the request of one of the parties to refer him to the arbitral tribunal and required the court to proceed in this regard, such as the arbitration law adopted in 1957 and Article 10 of the amendment law of some of the laws of the 1976 court, even in the bill on investigation, exploration and extraction of oil across the country and the continental shelf approved in 1957 and in the development of petrochemical industry act approved in 1965, required the referral of disputes to arbitration and foreseeing this in the contract. (Page 518) Article 43 of the Law of the Cooperative Section of the Islamic
406

Republic of Iran also provides for the referral of the dispute to the proceedings regarding cooperative companies.

Today, we see a wide range of legal opinions on the basis of the discretion of the judges to decide on their own competencies. For example, while some legal writers believe that authority and jurisdiction (competency) of the judges is the basis of arbitration agreement, because the integral part of the life and validity of the arbitration proceedings is the consent and agreement of the parties. Others, because they have considered the qualification competency (jurisdiction) as inherent in arbitration tribunals, consider it to be independent of any arbitration agreement. Also, many authors have documented jurisdiction and qualification competency, based on the rights of the country where the arbitration and the rights of each country to which the agreement is to be implemented. Ultimately, other authors suggest that the authority and competence to determine jurisdiction (qualification) can derive from customary rules that would otherwise waive the right to invoke the provisions of the domestic law (Redfern- page 345). 


\subsubsection{Contractual Basics}

In the second paragraph of Article 2 of the International Commercial Arbitration Rules, the legislator has allowed individuals who have a civil dispute to relinquish access to the state court, and to give their decision to a non-governmental judge elected by him, who is called the arbitrator. This reference is based on the will of the parties as follows:

An agreement on arbitration, in a general sense, is the consent of at least two sides for referring a judgment as to the existence of a civil dispute or a possible future dispute arising from a legal relationship with a person other than a state judge (Morteza Yousefzadeh-Page 25).

The aforementioned agreement, which is concluded principally in the form of an arbitration agreement, shall be agreed upon by the parties, according to which the parties agree that their existing dispute, either in court or not, or controversy and possible dispute that may occur in the future, , has been defined for referral to one or more individuals for the consideration of a decision (Abdollah Shams-i-III - page, $520)$.

Legal writers have provided judging divisions for referral contracts to arbitration based on the time of their conclusion as well as the referral method, which, in a quantitative division into contracts preceding the dispute and controversy and subsequent contracts, have divided.

In accordance with Article 455 of the Civil Procedure Law, the parties have the right to appeal to arbitration in two forms. One is to agree to negotiate and agree on the terms of the stipulation, either in agreement with the contractor, or in the form of a contract with stipulation, or in the form of a contract for the original contract, in case of a dispute between them, refer to the arbitration. The terms of the arbitration in the contract shall be subject to its disagreement and, if agreed between the parties, it happens that there is no dispute between them and does not exist. Conversely, the arbitration convention is concluded as an independent contract when there is a dispute between the actual parties (Homayoun Mafi, p. 58).

Therefore, given that the arbitration is of a contractual nature and 
the arbitrator obtains the authority and power of the parties to the agreement (arbitration agreement), and the existence of arbitration depends on the will of the parties, contrary to the judicial authorities who derive their competence from the public power of law and in that, the agreement between the parties is not a condition, jurisdiction of the courts of arbitration arising from the agreement of the parties. The arbitration agreement, as a private contract, limits the powers of the parties, and the arbitrators shall be obliged to respect the will of the parties in this regard. Any change in the nature of the controversial agreement may be the arbitrator's violation of the limits of powers granted to him by the parties to the contract. The authority of the arbitrators is within the scope of the contract parties' forecasts, and they are those who can extend or limit the authority and jurisdiction (competency) of the judges, therefore, the extension or limitation of the authority of the judges has a contractual basis and reflects the arbitration agreement. Internationally established practice in international arbitrations implies the acceptance of the jurisdiction (competence) of arbitrators in their own jurisdiction (competence) (Homayoun Mafi, p. 210).

It therefore seems to be possible to conclude that when the parties have the ability to decide that an arbitral tribunal should not determine its jurisdiction (competence), they shall also a fortiori be empowered to determine the scope and extent of its competence (jurisdiction).

The parties' intentions are one of the facts that the Iranian and US Court of Arbitration sets by virtue of that jurisdiction (competence). It is not necessary that the intention of the parties in the assignment of jurisdiction (competence) to an arbitral tribunal be specified in particular manner, but it is also inferred that the intention of the relevant circumstances, including the circulation and progress of arbitration (j.gillis wetter-at5).

\subsubsection{Legal Basis}

Arbitration, if is not due to consent and agreement of the parties in the referral of the matter to the arbitral tribunal and the referral to the arbitration is determined by law, the arbitration is 
compulsory or legal (Homayoun Mafi, p. $52)$.

Forced arbitration was initially envisaged in the law of 19/03/1928, according to Article 1 of this law, whenever a lawsuit (claim), a litigant of a court, demand peace of innocence and commerce from the court, discontinuation of the lawsuit is carried out through arbitration, the court will obligate the other party of lawsuit to accept this request and will be handled in accordance with the following. Provided that the application for arbitration has been filed before the end of the first trial and the lawsuit has been filed on that indulgence court.

In accordance with Article 17 of the Law on the Establishment of the Securities Exchange Act of 17/5/1966, the exchange arbitration board, which is formed on a permanent basis, deal with disputes between the brokers and between sellers or buyers or brokers arising from transactions in the exchange. The legislator in 1974 and Article 5 of the Family Protection Act stipulated: The court, upon request of either party, is required (obliged) to refer the matter to the referee, with the exception of the consideration of the principle of marriage and divorce. The court will also refer the dispute to arbitration if it is suspected.

Several years later, the legislator, in Article 10 of the Law on Amendments to some of the Laws of the Court of Justice, has declared: "In any legal action, except for the cases specified in Article 675 of the Civil Procedure Code, which was filed before the adoption of this Law and until the date of enforcement of this Law, it has lasted five years, whether initially or in the course of research, the main plaintiff within two years, if the hearing termination is not announced, request settlement of the claim through arbitration in a written way.

In Note 2 of Article 3 of the Bill on the Law of the Civil Criminal Court of the year 1980, it was also stipulated that if a couple applied for divorce pursuant to Article 1133 of the Civil Code, the court first refers the matter to arbitration. If there was no compromise between the couples, the court will allow the couple to divorce.

In accordance with paragraph 2 of Article 2 of the International Commercial Judicial Commercial Code of 1997, all persons who are liable in the 
ISSN | 2179-7137 | http://periodicos.ufpb.br/ojs2/index.php/ged/index

course of a dispute can refer their international trade disputes arbitration, whether they are or have not been filed with the judicial authorities. In case of litigation at any stage, it may be referred to arbitration in accordance with the provisions of this law with mutual agreement.

Under Article 454 of the Law on the Enlargement of the Year of 2000, it is also clear that the companies that have the capacity to lodge a dispute can interact with each other in a dispute and controversy, either in court or not, and if the litigation at any stage of the proceedings, refer the arbitration of one or more persons.

According to Articles 36 and 37 of the Law on the Securities Market of the Islamic Republic of Iran, which was adopted on 22/11/2005 and replaced by the Stock Exchange Laws approved in 1966, the issue of the referral of the dispute to arbitration has also been foreseen.

In American law, there is also a form of compulsory arbitration in which the parties in the choice of arbitration as a method of resolving a dispute act with freedom, but they have no choice of the judge or the prosecutor (handler).
For example, in federal contracts, the parties to the contract can agree that, if there is a dispute, the matter will be examined through the contracts review body, but the other will not be able to interfere with the prosecutor (handler) (Abbas Karimi - page 59).

Article 1466 of the French Civil Procedure Code states that if one of the parties to the dispute objects to the principle of the jurisdiction (competence) of the judges or its limits, the arbitral tribunal is competent to review its jurisdiction (competency) and may decide on its validity and limitations of its jurisdiction (competency).

Article 186 of the Swiss Arbitration Law also considers the Arbitral Tribunal competent to decide on its jurisdiction (competency). Article 30 of the English Arbitration Act of 1966 has also empowered the Court of Justice to rule on jurisdiction (competency). Article 1052 of the Dutch Code of Judicial Procedure also defines the same rule.

In the various rules of international arbitration, it is also stated, so that Article 21 of the United Nations Commission International Trade Law (UNCITRAL), Article 6 of the ICC, 
Article 15 of the International Arbitration Rules of the US Arbitration Tribunal and Article 14 of the International Arbitration Rules of London also have granted the right to arbitrate jurisdiction.

The legislative process in different countries shows that the principle of jurisdiction in determining jurisdiction (competency) is a general and consolidated rule.

Article 16, paragraph 1, of the Iran's international arbitration law, has also declared in a similar provision, the tribunal may decide on its jurisdiction (competency), as well as on the existence or validity of an arbitration agreement. For this purpose, the arbitration clause, which is part of a contract, is considered as an agreement independent of the other terms of the contract.

\subsubsection{Contractual and Legal Foundations}

Some writers, considering insufficient the above principles, have combined the two abovementioned principles. According to this view, the principle of the freedom of contracts is subject to certain limitations everywhere. Considering eligible a judgment as an entity created in the scope of the contract does not necessarily lead to the conclusion that the parties are free to organize all of it in a way that they consider appropriate. If the opposing concept of this idea is preferred, it can't be implied that the arbitration has been chained by inappropriate rules and regulations. Therefore, it can be admitted that arbitration courts (tribunals) are part of a judicial organization of a country and at the same time, it is possible to recognize that they are not only originated from a private agreement which legitimate value is acknowledged by the government, but also is governed by it (Mohammad Hossein Bordbar, page 89 ).

In his report to the International Law Institute in 1952, Professor Sasser Hill explains it in detail. In his report, while acknowledging that the arbitration is rooted in a private agreement, he argues that arbitration can't go beyond all legal systems, because there must be a law that can validate recourse to arbitration and the implementation of the arbitration. Therefore, arbitration is a establishment with a mixed competence, of its own origin, which is rooted in the 
parties' agreement and takes its qualification from the civil law (-94).

\section{Qualification (Jurisdiction) Issues}

Agreeing parties to refer a dispute to arbitration, whether before or after the dispute, is a necessary condition for referring the dispute to arbitration, but it is not sufficient because the arbitration agreement, in addition to the elements of the contracts and permanent credentials, the referee must also have a certain qualification. The purpose of the qualification (jurisdiction) is that the referee has the conditions desired by parties. Contrary to the jurisdiction (competence) of the subject, upon which receipt, the referee will have the subject matter from the beginning to the end of the hearing, in reviewing the competence of the arbitrator, in addition to the general rules of jurisdiction and the special conditions of arbitration in the relevant laws, the parties to the contract may determine his referral to arbitration of specific conditions that failure to do so, or the loss of that condition during the hearing, may result in the disqualification of the judge, therefore, it is necessary to consider the above issue in two main sections.

\subsection{Objections about the Aeferee}

When the task of resolving disputes is assigned to the judges (referees), by accepting the principle of competence (jurisdiction) in determining jurisdiction (competence), they will have a special place because they are the private judge to deal with the claims of the parties. As such, judges of the court have conditions that the absence of them will result in the referee's departure from the conditions required for issuing the verdict (decision).

\subsubsection{Competence}

The first condition for arbitration is to have competence. In many national legal systems, such as France and Germany, it is stipulated that judges must first be the real person and, secondly, have legal status (competence).

The International Commercial Arbitration Law does not explicitly refer to the necessity of the reality (being real) of judges, but in Article 1 (a), which 
ISSN | 2179-7137 | http://periodicos.ufpb.br/ojs2/index.php/ged/index

reads as follows: "arbitration is the elimination of disputes between laws outside of the court by a person or natural or legal persons with designated nature or agreed by parties».

In the case of judges' competence, there is no express provision in the International Commercial Arbitration Law, but according to the general rules it is not possible to consider valid the arbitrary verdict without competence. According to the Iranian legislator, in Article 476 of the Civil Procedure Law, the persons without legal competence can't be chosen as judge, even with agreement of parties, however the provisions of Article 466 of the Code of Conduct will naturally also be subject to international arbitration. Of course, Article 14 of the International Commercial Arbitration Law can also be inferred that it has been argued that if an arbitrator is, by law, or, for example, he/she isn't capable to perform his/her duties, his/her responsibility shall be terminated.

\subsubsection{Judges Who Are Prohibited from} Doing So
In the Code of Civil Procedure, the cases referred to by the arbitrator as defects are in the second paragraph of Article 466 of the above law: Those who have been deprived of arbitration by virtue of a definite court ruling or in consequence of it. Also, in paragraph 6 of Article 489 of the same law, the issuance of a decision by judges who were not authorized to vote (ruling) is considered for reasons for its cancellation.

\subsubsection{Independence and Impartiality}

The right to have independent and impartial judges is not allocated merely to the judges of the judiciary. In the arbitration, the parties have the right to decide independent and impartially arbitrator and arbitrator decide to resolve their disputes and because the parties have agreed that their dispute - is resolved with the private mechanism arbitration, it does not mean that the parties have denied their rights to such a right that is recognized globally as one of the fundamental human rights. It is not important that justice is only implemented, but more importantly, justice is seen openly and without any 
doubt to be executed (Cristopher Koch, Standards and Procedures for disqualifying the arbitrators, Translation by Alireza Ibrahim Gol - No. 36).

Article 6 of the European Convention on Human Rights also points to this issue as one of the fundamental and accepted principles of international arbitration that judges must be impartial and independent and remain in the process of reviewing such qualifications.

\subsubsection{Independence}

Independence of the judge means that the judge or judges should not have any (relative or causal) association or conflict of interest with either party. Independence as a whole is considered as an objective and fact-based standard. In order to determine this, it is necessary there is no actual or past relationship between the parties and the judges that may or at least apparently to affect the freedom of judgment and judgment of the arbitrator.

Lack of independence is clear in the cases that the judge has financial or non-financial benefits as a result of the case. One of the most widely accepted legal rules governing independent judgments is that nobody should be the judge of his/her case. Therefore, the major managers of the companies of the parties to the dispute are not suitable judges. . It does not matter whether there is a real threat of advocacy and partiality. In contrast to small shareholders whose stock value does not greatly affect the outcome of arbitration, it may not necessarily lack of independence (Julian Diamond Luke-Lucas Mistyllis-Stephen M. Kroll-Page 278).

\subsubsection{Impartiality}

Impartiality in the word means that it is necessary to observe the equality between the parties, as if in legal dictionary, impartiality means the position of an individual in a dispute that does not relate to any party of the dispute.

The meaning of impartiality is that arbitrating to one of the parties to the lawsuit, or the subject that the judge must decide for it, does not show willingness or discord. Unlike the judge's independence, to assess the judge's impartiality the subjective criterion is used (Christopher Cook, ibid). 
Impartiality is also defined by the absence of any obligation and responsibility of the arbitrator (judge) to one of the parties (Hamed Masoumi, Zeynab Barati, page 39).

Of the cases where the judge's impartiality is questioned if the judge has already expressed himself/herself in the exact legal issue or has acted as the advisor of one party in the matter (Julian Diamond Luke, Lucas Mistallis, Stephen M. Kroll-Page 276).

\subsubsection{Not having Specific Attributes and Conditions of Arbitration}

The parties to the arbitration convention may determine the special conditions for which the existence of those special conditions from the commencement of arbitration until the end of that period is necessary for the arbitrator's competence to do so, and the lack of any of them will eliminate the arbitrator's competence in issuing the verdict (decision). The English Arbitration Act 1996, Section 24, states that if the referee (judge) does not have the characteristics of the parties, then at any time by the court he/she can be dismissed. The most important features that international organizations determine for arbitration are as follows.

\subsubsection{Mastery of legal issues}

Given that many issues are legal issues, the judges for judging must be fluent in legal issues. According to Article 27 of the International Commercial Arbitration Law, the arbitral tribunal must decide in accordance with the rules of law.

\subsection{Familiarity with Business, Industry, and Industry Relevant to the Issue of Dispute}

Considering that today the important commercial and industrial matters and the specialized matters are referred to arbitration, it is very important for the parties that the arbitrator agreed by parties should has the expertise and be specialist in the matter of dispute, although the same judgment of the courts allows the referral of technical and specialized subjects to specialist experts, but the parties to the arbitration choosing the referee prefer that the arbitrator, with the technical 
knowledge of the subject, himself as a specialist, comment on the dispute.

Clause 4 of Article 27 of the International Commercial Arbitration Law states that the Arbitration Tribunal must decide in all cases in relation to the commercial law of the subject matter. One of the reasons for referring the dispute to arbitration is the use of the expertise and experience of the referees on the subject of the dispute.

\subsubsection{The Language of the Judges}

Basically, given that complex issues of arbitration and contract matters require interpretation, the full familiarity with the language of the contract or the language of the parties is one of the requirements for conducting arbitration, which generally traditional languages are used in international relations. Under Article 21 of the International Commercial Arbitration Rules, the language of the arbitration will include any bill, document and reason for the parties to the negotiations, hearings and voting (ruling).

\subsubsection{Complaints about the 450).}

416

Except in certain cases and due to the will of the legislator, individuals can't be forced to accept arbitration, contrary to their will. Because the resolution of the current or future disputes in arbitration must be accompanied by mutual consent otherwise have no usefulness and a sign of this consent is the arbitration agreement. In fact, the agreement on the arbitration is the first and most important condition for the creation and birth of the institution of arbitration (Mohammad Hadi Bakhtiari Farr-49). Therefore, to appeal to the arbitration agreement, it has been applied in two general ways.

\subsubsection{Discredit (Invalidity) of the}

\section{Arbitration Agreement}

The arbitration convention is the basis of the jurisdiction and legality of the reference for arbitration. If, for any reason, the arbitration convention is not valid (credit) or void or that it lacks one of the essential conditions for the validity of the transaction specified in Article 190 of the Civil Code, the arbitration court shall be deemed to be ineligible (incompetent) (Homayoun Mafi, page, Arbitration Agreement 
In accordance with article 7 of the International Commercial Arbitration Rules, an arbitration convention must be signed in the form of a document by the parties. Based on this, writing is one of the essential conditions of the arbitration convention document. For this reason, two reasons have been introduced.

The first reason is related to the written conditionality, to ensure the parties agree to arbitration and to refuse to disregard the agreement. The second reason for writing the arbitration clause is to record and register the agreement between the parties and to prove the existence and content of the arbitration convention in the subsequent proceedings. According to Article 5 of the New York Convention, the implementation of the arbitration convention is subject to written agreement between the parties. An arbitration convention can be found to be non-valid in two aspects. Of the form, the most important factor in the invalidity of the arbitration convention is the condition of writing or written arbitration agreement.

From the material aspect, the arbitration convention must have the essential conditions of the transaction's fairness, which is also the case in other contracts, including the intention and the consent of the parties, their competence, the particular subject matter that is traded and the legitimacy of the transaction (ibid.).

The International Commercial Arbitration Rules of Iran also in the case of cases of invalidity of the referral contract for arbitration, in clause (b) of Section 1 of Article 33 states: the arbitration convention is not valid under the law that the parties consider to be the governing agreement and in case of silence of the ruling rule, is outright opposite of Iran's law, has been has considered invalid. In the law of UNCITRAL, it also draws up the same rules, with the difference that, in the absence of the agreement, the law determines the place of arbitration.

\subsubsection{Ability to Judge}

Although arbitration is today the most common way of resolving international trade disputes and the growing willingness of countries to develop and eliminate obstacles to its evolution, but according to the laws of 
most countries, the resolution of some issues through arbitration continues to be faced with legal obstacle. In most cases, this is related to specific features of the subject, which, irrespective of being domestic or international of related arbitrary, is considered not arbitrated, but in some cases also the inability of arbitration in International Commercial Arbitration is due to the international aspect is the issue and foreign agent's involvement in arbitration. The issues that are considered not arbitrated as usual don't have merely private aspect and are also public, and perhaps their public aspect may be overcome by their own private aspect. Therefore, the criterion of arbitrariness implies the observance of public law and the safeguarding of national interests in resolving disputes (Berg -bertjan, the new York arbitration convention of 1958, Kluwerlaw and tax publishers 1981, p369).

The ability to judge refers to restrictions that each country imposes on arbitration for the protection of certain interests by referring arbitration to certain matters. These restrictions, which are derived from public order, may vary from any society to another and from time to time. These restrictions specify the extent of the will to determine the dispute resolution system (Javad SeyediPage 12).

\subsubsection{Ability to Judge in International} Law

Today, the principle is based on the arbitration of issues in international law, but lawyers have raised objections to disputes arising out of commercial competition rights or intellectual property rights and rights in securities.

In Articles 736 and 737 of the Argentine Civil Procedure Act, any dispute between the parties, except for disputes which can't be the subject of conciliation and settlement by the parties, may be referred to arbitration. In accordance with Article 1 of the Swedish Arbitral Tribunal, only the disputes concerning the subjects to which the parties have contractual freedom can be arbitrated. Consequently, the subject matter of public law is not open to arbitration. In accordance with French Civil Law in Articles 2059 and 2060, the parties may also any dispute that have freedom in its determining, except for public order issues, but now In France, the situation is such that international 
ISSN | 2179-7137 | http://periodicos.ufpb.br/ojs2/index.php/ged/index

judges are not prohibited from making decisions on issues of general public considerations because the French Court of Justice has declared that the provisions of Articles 2059 and 2060 are not applicable to international arbitration, so today the French courts admit that referees can handle disputes over antitrust, intellectual property, bankruptcy, and registered rights, even though these issues are universally qualified.

Although arbitrariness and public order are same rooted, but each of them arise at a different stage, and they are, in essence, pursuing different issues. The issue of public order in relation to the content of the verdict is raised, and seeks to guarantee this it is an issue that has not violated the standards of public order in a country that would invalidate or prevent the identification or execution of the decision, which is why in international documents both at the New York Convention and in UNCITRAL sample law is raised only after the issuance of the arbitrator's ruling, and in discussing the arbitration agreement, speaking of which not mentioned, While the ability to deal with a dispute is raised, whether at the time of the recognition of the arbitration agreement or at the time of the revocation, or the identification and enforcement of the arbitration, the ability to refer a dispute to arbitration is examined. That's why, it is raised in the New York Convention, Article 2 deals with the Arbitration Agreement, as well as Article 5, which relates to the identification and enforcement of the judgment. (See page 25).

\subsubsection{Ability to Judge in Iranian} Law

The Article 34, paragraph 1, of the International Commercial Arbitration Law, which has been adapted to the law of the UNCITRAL example, prohibits cases which, according to the domestic laws of Iran, are not capable of referral to arbitration.

\subsection{The Constitution}

In order to understand the issues that are not subject to arbitration, the Constitution of the Islamic Republic of Iran must first be referred to. Article 139 of the Constitution provides: Peaceful litigation regarding public and governmental property or its referral to arbitration in any matter is subject to approval by the Cabinet of Ministers, 
and it must be informed to the parliament. In cases where the lawsuit party is foreign and in important domestic cases must also be approved by the parliament. The Guardian Council has also stated in the interpretation of this principle in any case that the operation of the state or the official is based on the law, is approved by the Islamic Consultative Assembly, only in the approved range is legal and outside of that scope, except in part or in full, requires the passing of the Islamic Consultative Assembly (Theory No. 9993 - 8/9/62 and Theory No. 5606 7/12/1993).

The judicial interpretation of the above principle and the theory of the Guardian Council in various cases have not been in the same form. Some using the distinction between the functions of government and public institutions, saying that:

When a state-owned tangible corporation is a business and possesses property not for the exercise of the sovereignty but for business purposes, it is not prohibited to refer to arbitration and Article 139 of the Constitution and Article 457 of the Civil Procedure Law do not apply to individuals, that firstly, they will conclude an arbitration agreement with the state-owned companies that are acting in the company and, secondly, if the arbitration award is at their disadvantage, they will deal with the aforementioned cases regarding the revocation of the arbitral tribunal (Proceedings of 13.2.29.198 in the Classical case of 27th of 86th / 27th branch of Branch 27 of the Tehran General Court).

The same opinion about the property of private companies and corporations that in some ways, government executives or supervisors are appointed to them after the victory of the revolution (Islamic revolution) by the Algerian Committee on the review and modification on 21/11/1982, which states that in the case of the claim is for a private legal person governed by state management or supervisor, Article 139 does not apply because the provisions of the said principle apply to state or public property, and the ownership of personal property rights of private law does not change with the installation of a state manager or supervisor (Liaia Jenidis page 92).

These opinions are generally based on the distinction between state 
affairs in the exercise of sovereignty and what the state does in the conduct of its enterprise, since the legislator's term from article 139 of the Constitution of the Islamic Republic of Iran is public and state property that is used to govern the government which is to exercise sovereignty with the government and government companies and is apart from doing business and trade affairs.

In contrast, some government and government agencies and stateowned companies are not allowed to refer to arbitration unless approved by the Cabinet of Ministers and informed by the Assembly on internal and internal important affairs and in matters relating to relations with foreigners with the approval Cabinet of Ministers and ratification of parliament.

Based on this principle, in an instance of the court's verdict, according to Article 139 of the Constitution, the arbitrator has decided to issue a ruling that is in direct conflict with the rules give rise to the right, therefore, for not obtaining the resolution of the Cabinet of Ministers and the issued verdict is against the constitutional laws and specified laws (Proceedings No. 221200948-23 / 6/88 of Classes
$88 / 12 / 600$, Branch 12 of the Appeals

Court of Tehran Province)

\subsection{Rules of Claims}

Article 496 of the Code of Civil Procedure and Civil and Civil Revolutionary Courts of 2000 did not consider some of the claims to be arbitrary.

\subsection{Bankruptcy Cases (lawsuits)}

According to clause 1 of Article 496, this case (proceeding) can't be referred to arbitration, but about this that the lawsuits (claims) related to bankruptcy, such as a negotiated agreement or a lawsuit for revocation and termination of a negotiated contract, can't be referred to arbitration or no there is no consensus. Some argue with this that effects of such claims in addition to the parties to the claim to other persons believe that it is impossible to refer it to arbitration (Abbas Karimi, p. 120). However, it is tempting to interpret the exceptions in detail, in addition, the fact that the relationship of this claim with third parties isn't a strong reason for inability of the trial judge (arbitration), 
since most of the claims directly or indirectly relate to the rights of third parties, and, given the acceptance of the possibility of monitoring the submitted verdicts (decisions) by the authorities, fears of any harm is ended to third parties.

\subsubsection{Claims about the principle of} marriage, its termination, divorce, and its descendants

By virtue of paragraph 2 of article 496, the aforementioned cases (claims) are considered not being arbitrated. However, in the case of marriage or divorce claims (such as divorce and alimony or custody), the possibility of their referral to arbitration has been accepted, because the above affairs are directly related to the social ethics and religious rules of the parties.

\subsubsection{Referral of disputes between the} marine transportation officer and passengers before the occurrence of the dispute

According to Article 118 of the Marine Law 1964: if before the incident causing damages, in the contract, the conditions have been issued for the purpose of constructing the transportation officer, or in the case of limitation of liability, a sum less than specified in this chapter is determined, or in cases where proof is required by the locally employed locator, to be changed, or the condition that the disputes be referred to arbitration or a court, the aforementioned conditions are null and void.

\section{Conclusion}

Nowadays, with the expansion of trade relations between natural and legal persons and the growth and development of international trade, the need for resources that can quickly and accurately meet the parties' demands is more and more needed. Therefore, the growth of the issue of arbitration authorities with a great deal has been done. The coordination and creation of similar process in these institutions requires the analysis of various issues and the establishment of general rules that all the institutions of arbitration will follow it, which will make it possible for those referring to the above institutions and actors in the realms of trade is also 
aware of their circumstances and with knowledge of the issues, they are going to refer to the institutions of arbitration.

Considering that institutional arbitration is a substitute for referring to the judiciary, which is both willing and mutually consent and would provide better conditions for it, therefore, it was initially assumed that the referee, like the judge of the court, should have a general jurisdiction in respect to the private aspect of the proceedings, in order not only to fulfill his or her designated task of arbitration, but also the essence of arbitration, which is speeding up proceedings. Therefore, in the hypothesis that it is possible to deny the jurisdiction of the arbitrator in determining his competence, removed the subject of the proceedings from his/her hand, we will be faced with these substantive objections that judgment will be removed from its original character. In addition, by accepting the possibility of challenging the referee's decision, any objection to arbitration (including the personal jurisdiction of the referee or the arbitration institution or the invalidity of the contract) may be reviewed in another instance. Therefore the issue is subject to the discretion of the arbitrator, before the decision is taken out of the ordinary proceedings.

This view has led the most legislature's international institutions and the various countries, believing in the principle of the competence of the arbitrator in determining their jurisdiction, to believe that whenever one party, for any reason, objects the jurisdiction of the arbitrator (referral institution) and the referenced matter, the matter is raised and the referee commented on this issue, but this opinion is objectionable to the judicial authority.

\section{References}

Ahmad Matin Daftari (2009) Civic and Commercial Law, Tehran, Majd Publication, Third Edition

Abdullah Shams (2006) - The full text of the Civil Procedure Code-Drak- Tenth Edition

Morteza Yusfzadeh (2013) - Rules of Arbitration - Publication and Printing Co. Second Edition 
ISSN | 2179-7137 | http://periodicos.ufpb.br/ojs2/index.php/ged/index

Homayoun Mafi (2016) Explanation of the International Commercial Arbitration Law of Iran - University of Justice and Administrative Affairs - First Edition

Abbas Karimi and Hamid Reza Parto (2013) - Internal arbitration rights Publication of Justice (Dadgostar)Second Edition

Julian D. M. Liu-Lucas Mystelis-Stefan M. Carroll (2012) International Comparative Business Tribunal -Mofid University - First Edition

Hamed Masoumi, Zeynab Brayat (2015) Referee Injury in International Commercial Arbitration, Behnamy Publications, Tehran, First Edition

Javad Seyyedi (2013) - The Impact of Referral Ability in International Commercial Jurisdictions - Jungle Publication - First Edition

Laia Junidy (2013) - International Commercial Law EnforcementPublication of the City of KnowledgeThird Edition \#
Mohammad Moein (2009) Moein dictionary, Amir Kabir Publication House, Tehran, Twenty Sixth Edition \# Mohammad Jafar Jafari LangroudiExpanded Terminology- Ganj Danesh Publication-Fourth Edition

Mohammad Hussein Bordbar, Competence in International Arbitration Courts (2005) - - Ghoghnoo (Phoenix) Publications - First Edition \#j.gillis wetter-the international arbitration process-public and private-oceana publications-inc-dobbs ferry-new York1979

Cristopher Koch(2003). Standards and procedures for disgualifyingarbitrstorsjournal of international arbitration-\# Berg -bertjan, the New York aribitration convention of, Kluwer law and taxation publisers-1981

Ta Lee, Jack Tsen, Separability, Competence-Competence and the Arbitrator's Jurisdiction in Singapore, Singapore Academy of Law Journal, 1995

Ibrahim FI Shihata, The Power of the International Court to Determine Its 
Periódico do Núcleo de Estudos e Pesquisas sobre Gênero e Direito Centro de Ciências Jurídicas - Universidade Federal da Paraíba V. 8 - No 03 - Ano 2019 ISSN | 2179-7137 | http://periodicos.ufpb.br/ojs2/index.php/ged/index

Own Jurisdiction, Springer (eBook)(1965)

Redfern A et al, Redfern and Hunter on international arbitration, 5th edn. Oxford University Press.

Barceló, who decides the arbitrator's jurisdiction - separability and competencecompetence in transnational perspective. Vanderbilt Transnational Law Journal, 36-(2003) 